\title{
RETIREMENT PRIVILEGES OF CIVIL SERVANTS IN THE SECOND POLISH REPUBLIC
}

During the times of the Second Polish Republic the civil servants, teachers, the military, postal and railway workers were not covered by the universal social insurance, because before the social insurance act came into force, they were covered by pension systems guaranteeing more advantageous benefits. Persons working in state administration had a privileged position compared to the employees in general, both in terms of the scope and level of the benefits and their entire coverage by the State. The level of the pensions depended on the years of service and after 10 years of service amounted to $40 \%$ and was increasing every year by $2.4 \%$ or $3 \%$ up to $100 \%$. The civil servants acquired the right to the pension already after 10 years and as of 1934 after 15 years of civil or military service. In special cases they were entitled to pension after 5 years already.

Key words: Second Polish Republic, pensions, civil service, pension cover, social insurance.

doi:10.1515/sho-2015-0004

The 19th century was the time when the notion of a professional, advanced civil service emerged. It involved hiring officials who devoted their entire active life to the state. They had to carry out a number of specific responsibilities, well beyond the scope of a regular citizen's duties. The freedom of public servants was restricted in ways unknown to anyone else - there were limits to choosing the place they lived, expressing their opinions and performing any extra duties. On the other hand, also some of the privileges they enjoyed were exotic to regular citizens, for example, they had the right to special legal protection and to remuneration. One of the most highly regarded benefits was the right to a pension. This privilege was awarded to public officials in German states as early as the second part of the 19th century. They were later introduced in other countries and were an important element of the economic, social and legal sit- 
uation of professional officials, and, along with the right to job security, they were the foundation of the officials' privileged situation in society. ${ }^{1}$

The first regulations concerning the situation of clerks in Poland, rising after 123 years of occupation, had been published even before independence was officially reclaimed. On June 11, 1918, the Regency Council of the Kingdom of Poland published a rescript, which comprised temporary official regulations for public clerks, including a payroll. Section 23 includes a guarantee of retirement privileges for civil servants:

Retired officials are entitled to a pension, and in case an official dies, the widow and children will be financially protected. All this will subjected to a separate retirement act which is yet to be published. Until this act is published, the amount of the widow's or orphans' benefit will be settled in each and every case individually by the Council of Ministers (subject to later regulations), in accordance with the provisions of the future act. Furthermore a "death allowance" will be paid out, in the amount of 3-month earnings of the deceased. ${ }^{2}$

After the independence had been regained, Polish authorities had to regulate the legal situation of state servants. The Polish state created after the First World War comprised territories which had been under Russian, German and Austrian occupation for almost 150 years. Officials of the former occupying states represented varied moral and intellectual attitudes, knowledge of legal and administrative systems, they also had dif-

${ }^{1}$ Irich-Drabek Jolanta, Status urzędnika w XX-wiecznej Polsce: zarys problemu [Status of a public official in 20th century Poland: an outline of the issue], Społeczeństwo i Polityka 2009, no. 4, p. 15; Jaśkiewicz Wiktor, Studia nad sytuacja prawna pracowników państwowych [Studies on the legal situation of state employees], vol. 1, Formy prawne stużby państwowej w niemieckim państwie urzędniczym. Stosunek stużbowy w prawie urzędniczym RP [Legal forms of state service in the German clerical state. Employment in the Polish clerical law], AMU, Poznań 1961, p. 69. The 18th century witnessed the first attempts to provide some protection to widows and orphans of public officials in Austria. Later, regulations which financially support retiring state officials emerged. In Prussia, first such regulations were introduced in 1825, in Austria - in 1866, in the Kingdom of Poland - in 1816, and in Russia - in 1927 [for more information see: Okolski Antoni, Wyktad prawa administracyjnego [Administrative Law Interpretation,] vol. 1, Redakcja Biblioteki Umiejętności Prawnych, Warszawa 1880, p. 411-426; Wielka encyklopedia ilustrowana [The Great Illustrated Encyclopedia], vol. 19, Drukarnia Artystyczna S. Sikorskiego, Warszawa 1897, p. 264-273; Muszalski Wojciech, Ubezpieczenia społeczne [Social insurance], PWN, Warszawa 2004, p. 35-36; Muszalski Wojciech, Zagadnienie emerytalne funkcjonariuszy państwowych w Polsce (1918-1954) [State servants' retirement in Poland (1918-1954)], Studia i Materiały z Historii Ubezpieczeń Społecznych w Polsce 1988, vol. 6, p.18-19; Zbiór przepisów emerytalnych cywilnych w Królestwie Polskim [A collection of civil retirement regulations in the Kingdom of Poland], Warszawa 1871, p. 9-10.]

2 Journal of Laws [Dz. P. P. P.] 1918, no. 6, item 13. 
ferent qualifications and moral codes. ${ }^{3}$ They were the core of the administration staff at the time. In terms of figures, they were outnumbered by officials employed after the independence had been reclaimed, who were of various professions, and very often had had nothing to do with state service. $^{4}$

Due to the transient nature of the legal regulations of 1918, measures were taken to publish a new act, which would regulate the issues related to state service in a broad sense - including those of retirement and pensions. If the state had not provided a proper level of retirement income security to satisfy the officials, it would not have been able to ensure enough workforce to complete various public tasks. The right to pension, which would secure the future of public servants and their families, was an incentive to diligently fulfill professional tasks.

Since the beginning of its activity, the Parliament at various occasions discussed how difficult it was to run the administration and fill vacancies, as well as how inadequately the executive power was administered and the most important legal acts published. Bad economic situation in the country, due to e.g war losses and inflation, took its toll on the financial and moral standing of public servants. The parliament was well aware of this situation. As a result, regulating public servants' financial situation was the first step. At the same time, clerical reality was worked on. Members of the parliament shared a conviction that the efficiency of administration (crucial for completing various tasks in a country recovering from the war) can be improved by "awarding the clerical state a charter of rights and responsibilities" in the form of "professional pragmatism". It was expected that this would contribute to improving the professional, moral and disciplinary level among "young" officials. ${ }^{5}$

The first step of the Polish state in this respect was the introduction of the retirement act. Thus, the government wanted to gain the support of officials and professional army men during the economic crisis. The act of July 28, 1921 created a retirement system for state officials. ${ }^{6}$ The next act

${ }^{3}$ Kuś Bartosz, Stużba cywilna w okresie II Rzeczypospolitej [Civil service in the Second Polish Republic], Roczniki Nauk Prawnych 2014, no. 1, p. 146.

4 Jaśkieiwcz Wiktor, Studia nad sytuacja prawna... [Studies on the legal ...], p. 90.

${ }^{5}$ Ibidem, p. 79-80, 91.

${ }^{6}$ Journal of Laws [Dz. U.] 1921, no. 70, item 466; In the years 1918-1939, the word "pension" was understood as a salary paid by the state from the state budget to state employees who retired from service owing to old age or for other reasons. Pension was supposed to provide financial security for those who had spent years performing public duties. A popular illustrated encyclopedia, published by Trzaska, Evert and Michalski in 
was the act on state civil service of February 17, 1922, which entered into force on April 1, 1922, and in Section 46 guaranteed state officials the right to a pension. Their widows and orphans were entitled to widowhood and orphan allowance, in accordance with regulations provided in a separate retirement act. ${ }^{7}$

The act on state civil service regulated competences, professional hierarchy and the rights and responsibilities of public administration employees. In terms of requirements, it raised the bar for civil servants very high. Such high requirements were related to certain privileges and a high social status. According to the act, the work of civil servants started when they were delivered their nomination act. There were two types of nominations. There were permanent nominations and so-called temporary ones, which remained in force until the official was dismissed. Permanent officials took an official oath, temporary servants made a professional pledge. The act on state civil service introduced a division into clerks and lower public servants. Twelve professional ranks in particular categories were introduced, and the highest rank was the first rank. ${ }^{8}$ These ranks were abolished in 1933. Instead, twelve groups of basic salaries were introduced. ${ }^{9}$

Only a person complying with clearly defined requirements could become an official. Those requirements included e.g. Polish citizenship, impeccable past conduct, legal capacity and fluency in Polish. State servants

1927, explained the term "pensioner" in the following way: "a long-serving, dismissed civil or army official". [Ilustrowana encyklopedia Trzaski, Everta i Michalskiego z wieloma mapami, tablicami $i$ ilustracjami w tekście [Illustrated encyclopedia by Trzaska, Evert and Michalski with numerous maps, charts and illustrations], Lama Stanisław [ed.], vol. 1, A-E, Wydawnictwo Trzaski, Everta i Michalskiego, Warszawa 1927, column 1007-1008]. In relation to hired workers, who stopped working due to their age, other terms were used, such as age or disability allowance or income. In the territory of the Second Polish Republic, retirement insurance of blue-collar workers was only introduced with the so-called Reunification Act of 1933 [Journal of Laws 1933, no. 51, item 369]. Slightly earlier, in 1928, the act on white-collar workers' insurance provided insurance regulations for this particular group [Journal of Laws, 1927, no. 106, item 911].

7 Journal of Laws [Dz. U.] no. 21, item 164; Witkowski Wojciech, Historia administracji w Polsce 1764-1989 [History of Administration in Poland 1764-1989], PWN, Warszawa 2007, p. 374; Żyliński Tadeusz, Zaopatrzenie emerytalne stużby państwowej w okresie międzywojennym [Retirement provisions for state officials in the years 1918-1939], Acta Universatis Wratislaviensis, Prawo CXXI, Wrocław 1984, p. 134.

${ }^{8}$ Journal of Laws [Dz. U.] no. 21, item 164; S. Kasznica, Polskie prawo administracyjne [Polish Administrative Law], Poznań 1946, p. 90.

${ }^{9}$ A decree of the President of Poland was introduced on October 28, 1933 to amend the act of February 17, 1922 on state public service, Journal of Laws [Dz. U.] 1933, no. 86, item 661. 
had a number of responsibilities. According to section 21 of the act on state civil service they were obliged to:

[...] faithfully serve the Republic of Poland, observe laws and regulations, fulfill the responsibilities of the service diligently, meticulously and impartially, act in the public interest according to their best will and knowledge, and do everything that is good for the state and avoid everything that can harm it. ${ }^{10}$

They had to comply with orders of their superiors, as long as these were not against the Polish law. Obligation of professional secrecy was yet another issue. Special rules applied to civil servants in terms of their demeanor. They had to protect the dignity their position, and avoid anything that could jeopardize respect and trust for the position. They had to show respect to their superiors, be polite towards other employees and subordinates. In professional contacts with clients, they had to be serious, impartial, and offer council and assistance. They were not allowed to accept gifts offered in relation to their position and to undertake any other job or activity which could interfere with their professional responsibilities. Breaching those rules could result in professional, civil and legal penalties.

Civil state servants had a number of rights and privileges which, in a way, were supposed to compensate for their devotion to state service. The highest privilege was job security. Officials could be dismissed from the service only by a valid regulation of the authorities, issued in compliance with the provisions of the act on state civil service or based on the decision of a disciplinary committee. However, they could be transferred into inactive state, if, as a result of organizational changes, there were no suitable positions available. In such a case, they obtained their salary in full, and this time was counted as years of service. Public officials also had special rights in terms of holiday leave. ${ }^{11}$

They had the right to income in case of a partial loss in capability to work (as a result of an illness), during sick leave (for one year), or in the case of a leave granted to improve their health. Meanwhile, white-collar workers were protected against work contract termination due to illness only for three months, and blue-collar workers only for four weeks. Apart

10 Journal of Laws [Dz. U.] 1922 no. 21 item 164.

11 Ibidem; Pawłowski Jacek, Historia systemu stużby cywilnej w Polsce [The history of the civil service system in Poland], https://dsc.kprm.gov.pl/historia-systemu-sluzby-cywil nej-w-polsce-0, access on September 4, 2015. 
from the leave to improve health, unknown at all in the labor code, the act included paid "circumstantial leaves", allowing one to take care of one's family, personal or financial affairs, for the period of up to two months. The labor code only included short circumstantial leaves for white-collar workers, and offered nothing in this respect to blue-collar workers. Holiday leaves of public officials were longer than those of hired workers and were dependent on the years of service worked. ${ }^{12}$

State officials enjoyed certain special rights in terms of their army duty. Permanent officials drafted by the army remained employed in civil service, and were obliged to resume their duties after completing their army service. ${ }^{13}$ They were also entitled to discounts on train fares. ${ }^{14}$ They could obtain a company flat and other material goods. ${ }^{15}$ They could make expense claims in case they were relocated or worked away from home. ${ }^{16}$ Hired workers could benefit from those privileges only if these were included in their contract or in a collective agreement. ${ }^{17}$ The right to pension was an extremely valuable privilege of state officials. ${ }^{18}$

Public Officials Retirement Act of July 28, 1921 entered into force on October 1, $1921 .{ }^{19}$ Under the act, public servants were clerks or lower-rank public employees (i.e. a blue-collar worker employed in public offices), national rail workers, policemen, professors, university lecturers and academic assistants in state colleges, teachers of all state and public schools, judges, prosecutors and court applicants, excluding non-professional judges in the Courts of Peace in former Prussian and Russian territories who did voluntary work. ${ }^{20}$

12 Jaśkiewicz Wiktor, Studia nad sytuacja prawna... [Studies on the legal situation...], p. 134; Journal of Laws [Dz. U.] 1922, no. 40, item 334; Journal of Laws [Dz. U.] 1922, no. 21, item 164.

${ }^{13}$ Journal of Laws [Dz. U.] 1919, no. 59, item 357.

14 Journal of Laws [Dz. U.] 1934, no. 10, item 79; Journal of Laws [Dz. U.] 1936, no. 7, item 30 .

15 Journal of Laws [Dz. U.] 1934, no. 10, item 82.

16 Journal of Laws [Dz. U.] no. 35, item 320.

17 Jaśkiewicz Wiktor, Studia nad sytuacja prawna... [Studies on the legal situation...], p. 135.

18 Journal of Laws [Dz. U.] 1922, no. 21, item 164.

19 Journal of Laws [Dz. U.] 1921, no. 70, item 466.

20 At first, employees of the national rail were treated just like all other state servants. In 1929, a Council of Ministers' regulation, based on the provisions from 1926 on commercialization of the rail, regulated the Polish system of pensions for full-time rail employees, separately from the act on state officials from 1923. Therefore, a separate system was created for rail, which remained in the rail administration subjected to the Ministry of Transport. Retirement provisions for rail employees were based on the retirement act of 
The state retirement system provided for income in the form of pension, widowhood and orphan allowances and one-time benefits. The amount was dependent on the years of service and the group of salary. Widows were entitled to benefits regardless of their age and health. ${ }^{21}$

According to the provisions on civil service, state officials who were permanently nominated could receive a lifelong pension having retired due to permanent inability to continue work after at least ten years of state service. If they were permanently unable to perform their professional duties due to illness or disability, occurring through no fault of their own, they could retire after five years. Regardless of the years of service, they were entitled to retirement if they were permanently unable to work as a result of an occupational accident.

Retirement followed upon a formal request of the official who had turned 60 or 55 and had gained the right to pension. They could also retire regardless of age, if (as a result of a physical disability or loss of physical or mental capabilities) they became permanently unable to continue service. Public officials could be retired automatically, in case they had not worked for more than one year as a result of an illness, became permanently unable to work (as a result of loss in mental or physical capabilities), turned 60 and gained the right to full pension, ${ }^{22}$ or if within a year since being transferred into inactive state they were not called on duty. Rail workers could be automatically retired regardless of their age, if they had gained the right to full pension. ${ }^{23}$

Years of service, which were normally included in calculations of retirement seniority, were calculated from the beginning of the service in a given department of public administration. Time of inactive service, active service in the Polish army and the time worked in local authorities were included in years of service. Upon approval by the Minister of Treasury, the period of service spent as a hired worker could be taken into consideration when calculating the pension.

1923 [Muszalski Wojciech, Zaopatrzenie... [State servants'...], p. 45; Journal of Laws [Dz. U.] 1929, no. 57, item 448].

${ }^{21}$ Piątkowski Marek, Świadczenia emerytalno-rentowe ubezpieczeń społecznych w okresie międzywojennym [Pension and disability benefits in the social insurance system in the years 1918 to 1939], Studia i Materiały z Historii Ubezpieczeń Społecznych w Polsce 1983, vol. 1, p. 48 .

22 This provision did not apply to judges, whose retirement was regulated by a separate act [Journal of Laws 1928 no. 12 item 93] and college professors, whose retirement was regulated by the act on colleges [Journal of Laws 1920 no. 72 item 494].

${ }^{23}$ Journal of Laws [Dz. U.] 1921, no. 70, item 466. 
Rail workers had particularly advantageous rules of calculating their years of service. Rail workers who worked as engine drivers, loaders, adjusters and ticket collectors, had every year above ten years of service counted as 18 months. Rail workers who performed night duties, had each year above 10 years of service counted as 16 months.

Those workers who had worked in the administration of any of the former occupying countries before joining the Polish service had all years of service in the former occupier's service (subject to calculation in accordance with the retirement provisions of this country) and the years of service in the Polish administration counted when determining retirement seniority. ${ }^{24}$

Those state servants who did not earn the right to pension and were forced to leave their jobs due to inability to work resulting from illness or disability, and those who were made redundant due to restructuring, had the right to compensation in the amount of three-month wages. Voluntary resignation from the service or disciplinary dismissal meant losing the right to pension.

Pension was calculated based on the base salary, with seniority, higher education and managerial position bonuses added. After ten years of service, pension equaled $40 \%$ of the wages, every subsequent year meant a $2.4 \%$ increase. However, full pension could not exceed $100 \%$ of the active service salary (the base for calculating pension). To be entitled to full pension (the equivalent of $100 \%$ of the last salary) one was required to have worked for 35 years. ${ }^{25}$

Pensions were paid monthly, in advance, from the first day of the month following the decision to withhold the active service salary. The right to pension was suspended in three cases: if a pensioner was abroad for more than 6 months without the permission of the Minister of Treasury (suspension lasted until the end of this stay), if a pensioner lost Polish citizenship (until the citizenship was regained), and if a pensioner received a disability allowance based on other acts (if the benefit was paid from the Treasury budget).

Widows and children of the employees obtained widowhood and orphan allowance. Widowhood allowance equaled $50 \%$ of the deceased servant's pension. Widows of public employees who themselves had gained the right to pension for public service could choose between their own

\footnotetext{
24 Ibidem.

${ }^{25}$ Muszalski Wojciech, Zagadnienie... [State servants'...], p. 24.
} 
pension and widowhood allowance. Widows were not entitled to pension if marriage had been concluded by a pensioner or if the spouses were separated by court ruling without an obligation for the husband to financially support his wife. Also, children who were born in a marriage concluded by a pensioner were not entitled to an orphan allowance. If the widow remarried (unless she reserved the right to pension in case she was widowed again), she obtained a one-time benefit in the amount of a three-year widow allowance.

Every paternal orphan whose mother was alive and entitled to widowhood allowance was entitled to an allowance in the amount of $25 \%$ of the widow allowance. An orphan whose mother was no longer alive or was not entitled to a widowhood allowance when her husband died (or lost this entitlement) received an allowance in the amount of $50 \%$ of the widow allowance. The sum of orphan and widowhood allowances could not exceed the amount of the pension which the deceased employee actually received or was entitled to at the time of death. The orphan allowance was received until the age of 18, and if children were in higher education, until the age of 24. Also maternal orphans were entitled to the orphan allowance, but only in three cases: when the paternal orphan allowance was lower than the maternal orphan allowance; when orphans had no support from public funds; when the father was alive, but unable to work, and could not support the children. Maternal orphan allowance was $1 / 6$ of her pension.

Widow of a public servant who died before he gained the right to pension received (if she was not a public employee herself or did not receive pension) a one-time benefit in the amount of a six-month salary earned by the late husband in the last years of his active service. Double orphans under 18 received the same allowance after a mother or a father if the parents had not gained the right to pension.

Apart from the widow allowance, widows of public employees or pensioners, as well as their children, were entitled to the so-called death allowance, in the amount of a three-month full active service salary or a onemonth pension last received by the deceased. If the deceased did not have any wife or children, this allowance was paid to the next of kin, or to other people, to cover the cost of the funeral, if the deceased had not left enough money to cover this expense. Pension, widowhood and orphan allowance, and the death allowance could not be subjected to court or administrative confiscation. ${ }^{26}$

${ }^{26}$ Journal of Laws [Dz. U.] 1921, no. 70, item 466. 
In case of injury or death, a servant or their family was entitled to a compensation in the amount of two-year wages, independently from the pension. Additionally, when a servant died, their children received priority for enrollment in public schools and were entitled to free education. ${ }^{27}$

The retirement system for state servants was consolidated by The Act on Retirement Pensions for State Servants and Professional Soldiers of December $11,1923,{ }^{28}$ which, although amended on many occasions, remained in force until $1954 .{ }^{29}$ For civil servants, the scope of this regulation, compared with the 1921 act, did not change. However, it also included professional soldiers. ${ }^{30}$ The act applied to the police, border guards, and prison guards. It only concerned permanent officers. ${ }^{31}$

The act of 1923 introduced a type of a contribution, called a "fee". The fee was 3\%, deducted from monthly salaries of active servants, and from pensions. Only widowhood and orphan allowances were exempted. Regardless of the above, if the servant was promoted and received a raise, for the following year, half of the raise obtained was deducted as a fee. ${ }^{32}$ The act did not provide for the creation of a special retirement fund, as it happened in the case of social insurance, or for any kind of separate budget. The deducted fees lowered expenses for retirement pensions and allowances. As a result, the act introduced a specific system without any fund characteristic for social insurance. Fees were not returnable. They were accounted for as the Treasury's income. ${ }^{33}$

The act of 1923 introduced the possibility to add years when calculating the duration of service. To establish the amount of pension (as op-

27 Sperka Zbigniew, Zarys organizacji $i$ działalności Polskiej Straży Granicznej w latach 1928-1939 [An outline of the organization and the activity of the Polish Borders Service in the years 1928-1939], Przegląd Prawniczy, Ekonomiczny i Społeczny 2014, no. 2, p. 99.

28 Journal of Laws [Dz. U.] 1924, no. 6, item 46; The implementing regulation of March 26, 1924 was published in the Journal of Laws [Dz. U.] 1924, no. 32, item 320.

29 Journal of Laws [Dz. U.] 1954, no. 30 item 116; for more about pensions of professional soldiers see: Żarkowski Aleksander P., Wybrane elementy wojskowego ustawodawstwa emerytalnego Drugiej Rzeczypospolitej [Selected elements of military legislation in the Second Polish Republic], Zeszyty Naukowe Akademii Obrony Narodowej 2000, no. 1, p. 308-314.

${ }^{30}$ Earlier, retired professional military men received a pension in accordance with the act of August 5, 1922 on retirement provisions for army men and their families; Journal of Laws [Dz. U.] 1922, no. 68, item 616; Kula Henryk M., Polska straż graniczna w latach 19281939 [Polish Border Guards in the years 1928-1939], Wydawnictwo Bellona, Warszawa 1994, p. 78.

${ }^{31}$ Journal of Laws [Dz. U.] 1924, no. 6, item 46.

32 Muszalski Wojciech, Zagadnienie... [State servants'...], p. 24.

${ }^{33}$ Journal of Laws [Dz. U.] 1924, no. 6, item 46. Muszalski Wojciech, Zagadnienie ... [State servants'...], p. 24. 
posed to a claim for it), the time of military service and up to 4 years of university education were taken into consideration. The time of military service during a war was doubled. Participation in independence military organizations was also accepted. Rail officers (engine drivers and ticket collectors) and the employees of Polish Mail, Telegraph and Telephones (mail carriers) had every year of service counted as 14 months. If the state servant retired as a result of permanent disability resulting from a work accident sustained while on duty, infectious diseases contracted on duty, or war, between two and ten years (depending on the degree of disability) were added to their years of service. Based on the Council of Ministers' resolution, subject to approval by the Ministry of Treasury, the President of Poland could in special cases include in the calculation of pension years of service not normally accepted by the law, grant pension, and increase the pension which public servants, professional army men and their families were legally entitled to.

The years of service did not include time before turning 18 years old (except for military service), time of unpaid leave (except for leave awarded to perform parliamentary duty), time when the active service was suspended, and time deducted by disciplinary rulings.

The act of 1923 introduced the provision that pensioners can be reimbursed for the cost of a one-time relocation related to retirement, concession for medical services, rail journeys, stays in spas and, in case of a mental illness, placement in a psychiatric hospital on public expense. ${ }^{34}$

Until 1939, the act of 1923 was changed 13 times (7 times before 1931). ${ }^{35}$ From 1930, the government gradually submitted bills worsening the conditions stipulated in previous legislation, including the retirement act. ${ }^{36}$ Due to the economic crisis and the growing number of pensioners, the amendments made in this period reduced allowances and expenses. ${ }^{37}$

34 Ibidem, p. 25.

35 Journal of Laws [Dz. U.] 1924, no. 18, item 178; Journal of Laws [Dz. U.] 1924, no. 52, item 526; Journal of Laws [Dz. U.] 1926, no. 122, item 705; Journal of Laws [Dz. U.] 1929, no. 23, item 234; Journal of Laws [Dz. U.] 1929, no. 57, item 448; Journal of Laws [Dz. U.] 1930, no. 82, item 647; Journal of Laws [Dz. U.] 1931, no. 27, item 170; Journal of Laws [Dz. U.] 1932, no. 26, item 239; Journal of Laws [Dz. U.] 1935, no. 85, item 521; Journal of Laws [Dz. U.] 1939, no. 28, item 183.

${ }^{36}$ Kościński Wiktor, Z dziejów Państwowego Zakładu Emerytalnego. Refleksje i osobiste wspomnienia [From the History of the State Retirement Company. Reflections and Personal Memories], Studia i Materiały z Historii Ubezpieczeń Społecznych w Polsce 1985, vol. 3, p. 32.

${ }^{37}$ Michalski Jerzy, Zagadnienie emerytalne w Państwie Polskim [Retirement Issues in Poland], Skład Główny Drukarnia i Księgarnia Św. Wojciecha, Warszawa 1937, p. 32-38. 
The 1931 amendment brought about a significant change, which resulted from the introduction of retirement insurance for white-collar workers in 1928. The problem of relocating officials from public to private companies (and vice versa) was regulated at the time. In the case of a transfer from the public sector to a private company, the Treasury transferred $8 \%$ of the fee to the Intellectual Workers' Insurance Company, for the whole period of service. The situation was similar when an employee transferred to the public sector. In that case, The Intellectual Workers' Insurance Company transferred the contributions to the Treasury, which meant that the period when the contributions had been paid was added to years of service in the public sector.

Another amendment in pre-war retirement provisions was brought about by the Act on Pensions for Public Officials and Professional Soldiers of March 18, 1932. ${ }^{38}$ According to the new regulation, the time of service used as the calculation base for public servants' pensions was extended (from 10 to 15 years). The amount did not change however, it was still $40 \%$ of the last salary. For every year above those 15 years, the calculation base grew by $3 \%$, until the maximum $100 \%$ of the salary. Those provisions remained in force until the outbreak of the Second World War. The act of 1932 introduced (for a period of one year) an $8 \%$ pension fee for those retired before April 1, 1932. It also increased the amount of fee deducted from active officers' salaries to $8 \%$ - that is, to an amount equal to the contribution for retirement insurance in the case of white-collar workers. ${ }^{39}$

The amendment of 1933 extended the application of the retirement act to the so-called temporary workers - i.e. nominated until dismissal. ${ }^{40}$ Another important organizational change was also introduced. A State Company was established to pay out benefits from contributions made by the Treasury. Since the company had to collect the necessary capital and to create reserve funds, the reform was only implemented in part - only new employees (nominated after January 31, 1934) were included..$^{41}$ This way, two separate levels were created: there was the new system operated by

\footnotetext{
38 Journal of Laws [Dz. U.] 1932, no. 26, item 239.

39 Ibidem; Paciorkowski Jerzy, W II Rzeczypospolitej [In the Second Polish Republic], Policja 997, 2008, no. 8, p. 10.

40 Journal of Laws [Dz. U.] 1933, no. 86, item 668.

41 Journal of Laws [Dz. U.] 1933, no. 86, item 668; Kościński Wiktor, Nowy system emerytur państwowych. Państwowy Zakład Emerytalny [A new system of state pensions. The State Retirement Company], Księgarnia Powszechna Dzieł Prawniczych i Ekonomicznych, Warszawa 1934, p. 7; The charter of the Company was published in the Journal of Laws [Dz. U.] 1934, no. 31, item 276; The history of the establishment and the first years of the
} 
the Company, and the old one, operated by the Treasury offices in accordance with the old rules. Limiting the operation of the Company to newly nominated officials only delayed the beginning of pension payouts by 15 years. Before that, the company only paid out disability benefits or widowhood or orphan allowances. As a result, the Company started to collect a substantial capital, which was located in debenture bonds, financing the trade fleet and, to a lesser extent, in real estate.

The amendments from 1935 and 1938 provided for further limitation of benefits, by introducing periodic fees and restricting the advantageous calculation of years of service e.g. for fighting in wars. From 1938, retirement regulations also included state servants working in Zaolzie, an annexed territory. In 1935, pensions were subjected to a payroll tax and to the increase in income tax. ${ }^{42}$ The last amendment, in 1939, only concerned military men, who were excluded from the operation of the Company, and who were to receive benefits directly from the Treasury. ${ }^{43}$ In 1935, the group of state servants included 446,000 active workers and 400,000 pensioners. In 1924, the state spent $2 \%$ of its expenses on pensions, in 1935 $8 \%$. Considering the economic situation at the time, this was too much of a burden for the state budget. ${ }^{44}$

According to pre-war provisions, retirement pensions for state servants and professional army men were paid out using the provision method. Because of that, the concept of the retirement system for officials differed significantly from the general retirement insurance system. Although in both cases there was a retirement fund created using contributions, only in the general system both employees and employers bore cost of it by paying the contributions. Contributions for the retirement provision of state employees were paid by the state. The fund for the retirement provision for state employees was not autonomous from the budget, because the state guaranteed payments in the amount stipulated by the retirement act. There were no such guarantees in the general system. The amount of the retirement pension in the general system depended on the period of paying social insurance contributions (in order to obtain the right to pen-

Company's operation was described by Wiktor Kościński, the first director of the Company. See: Kościński Wiktor, Z dziejów...[From the history...], p. 25-46.

42 Journal of Laws [Dz. U.] 1935 no. 85 item 521; Journal of Laws [Dz. U.] 1938, no. 90 item 615; Muszalski Wojciech, Zagadnienie ... [State servants'...], p. 27.

43 Journal of Laws [Dz. U.] 1939, no. 28, item 183; Muszalski Wojciech, Ubezpieczenia... [Social insurance], p. 58.

${ }^{44}$ Piątkowski Marek, Świadczenia... [Pensions and...], p. 48. 
sion, one had to have turned 65 and to have been paying the contributions for 40 years in the case of white-collar workers, and for a minimum of 200 contribution weeks in the last 10 years in the case of blue-collar workers).$^{45}$ However, in the retirement system for state servants, contributions did not matter, because the amount of pension was determined by the years of service. ${ }^{46}$

Anna Jarosz-Nojszewska - PhD, Warsaw School of Economics, Department of Economic and Social History. Scientific interests: economic history, social insurance, pensions, civil service, Second Polish Republic.

45 Journal of Laws [Dz. U.] 1933, no. 51, item 396.

46 Babińska Renata, Systemowe zagadnienia zabezpieczenia emerytalnego wojskowych [Problems of the system of military retirement insurance], Acta Universitatis Wratislaviensis Socjologia 2008, no. 3079, p. 262. 